\title{
BOHACSEK DÓRA
}

\section{NATURA ÉS CULTURA \\ Vulgáris és klasszikus latin Afrikában: africanismus-e a labdacismus?*}

A Római Birodalom fokozatos térhódításával a Róma városában és annak környékén beszélt latin nyelv idővel egy hatalmas terület közvetítő nyelve lett. A meghódított provinciák nyelvi romanizációja lassabb folyamat keretében történt, mint maga a hódítás - ennek megfelelően egyáltalán nem mondható egységesnek, illetve nem minden régióban valósult meg teljesen. ${ }^{1}$

A ma klasszikus latinként ismert, szabályozott irodalmi kultúrnyelv mellett beszélnünk kell egy folyamatosan változó, élő latin nyelvről, a sermo vulgarisról is, melynek feltehetőleg területi változatai is kialakultak a császárkorban. Az úgynevezett vulgáris és klasszikus latin közötti eltérésekre már az ókorban is felfigyeltek, számos késő antik grammatikusnál olvashatunk olyan feljegyzéseket, melyek a latin nyelv sokszor helytelen, a klasszikustól eltérő használatára vonatkoznak. Ezek közül néhány forrás területi sajátosságokat is megemlít, így több grammatikusnál találunk az afrikai latin nyelvre vonatkozó megjegyzéseket, például a labdacismus kapcsán, amelyet néhányan már a késő ókorban is africanismusnak tartottak. Tanulmányomban ezt a nyelvi jelenséget vizsgálom meg. Először sorra veszem az ide vonatkozó grammatikusi helyeket, majd a gemináció kapcsán áttekintem az afrikai feliratos anyagot, melyet végül összehasonlítok Róma városának feliratos anyagával - a Császárkori latin feliratok számítógépes nyelvtörténeti adatbázisa (továbbiakban Adatbázis) segítségével -, feltéve a kérdést: Vajon mennyiben tér el e tekintetben a távoli, részben perifériának számító terület nyelve az Imperium Romanum fővárosának és központjának nyelvétől, igaza van-e a latin grammatikusoknak?

Amennyiben az afrikai latinság sajátosságait szeretnénk vizsgálni, különbséget kell tennünk az irodalmi igénnyel készült és a beszélt nyelvhez közelebb álló, irodalmi igény nélkül íródott szövegek között. A fennmaradt afrikai auktorok munkái retorikai iskolák termékei; szerzőik képesek voltak teljesen kizárni a pun, berber vagy egyéb nyelvi elemeket, még akkor is, ha pun származásúak voltak. ${ }^{2}$ Elég csak az afrikai származású Apuleius soraira gondolnunk, ahol a szerző maga reflektál erre, mondván, ugyan ki

* Jelen tanulmány a VI. Mathéma Konferencián (ELTE BTK, 2019. május 31 - június 1) elhangzott előadás átdolgozott változata, mely a Császárkori latin feliratok számítógépes nyelvtörténeti adatbázisa címü, K 124170 számú NKFIH-projekt keretében az MTA Nyelvtudományi Intézet Lendület Számítógépes Latin Dialektológiai Kutatócsoportjában készült.

${ }^{1}$ Herman J.: Vulgáris latin. Az újlatin nyelvek kialakulásának útja. Budapest 2003. 17.

${ }^{2}$ J. N. Adams: The Regional Diversification of Latin 200 BC - AD 600. Cambridge 2007. 570. 
nézne el vagy bocsátana meg neki hallgatósága és szerzőtársai közül bármiféle nyelvi hibát? ${ }^{3}$

A nyelvi változásokat tehát a normatív, klasszikus latinnak nevezett nyelvhasználattól elütő jelenségek formájában lehet vizsgálni, melyek legtöbbször az élő nyelv, a nyelvszerkezet változásait tükrözik. ${ }^{4}$ Nagy mennyiségű, jól lokalizálható és datálható szövegekre van szükség mindehhez, melyek csak viszonylag kis mértékben befolyásoltak a normatív nyelv által, és így lehetőséget adnak a vulgáris latin jelenségek, a vulgarizmusok megjelenéséhez. ${ }^{5}$ Éppen ezért igen értékes nyelvemlékek a feliratok, melyek a kevésbé művelt kézművesek, munkások - tehát a hétköznapi emberek - beszédét és nyelvét tükrözik. Keletkezési helyüket és idejüket elegendő pontossággal lehet meghatározni, ${ }^{6}$ és a Római Birodalom minden területén megtalálhatók, ráadásul nem kis számban, így a régiók szerinti összehasonlítást is lehetővé teszik. A vulgáris latin sajátosságait tükröző szövegek többségében önkéntelen tanúságtételek, melyek a szövegeket megfogalmazó vagy másoló személyek figyelmetlensége - vagy akár műveletlensége - következtében térnek el a hagyományos normától, az ún. klasszikus latintól. ${ }^{7}$ A már korábban említett Adatbázis keretén belül ezeket a feliratokon megmutatkozó ún. „hibákat”, tehát a releváns (úgymond hibás) és a normatív (klasszikus) szöveg közötti különbséget leíró kódok segítségével tudjuk rögzíteni, s végül az így kapott adatokat összehasonlító módon elemezzük.

Az afrikai latin nyelv sajátosságai kapcsán az egyik igen sokat emlegetett, kissé zavarosnak mondható jelenség az $l$ hanggal (betűvel) kapcsolatos tévesztés, közismertebb nevén a labdacismus kérdése, melyről bővebben Pompeius grammatikusnál olvashatunk az alábbi, nem teljesen világos szövegrészletben: ${ }^{8}$

Labdacismus est ille, qui aut per unum $l$ fit aut per duo; sed per unum, si tenuius sonet, per duo, si pinguius sonet. puta llargus; debemus dicere largus. ut pingue sonet; et si dicas llex non lex: uitiosa sunt per labdacismum. item in gemino $l$ [quando fuerint duo $l$ ], si uolueris pinguius sonare, si dicamus Metelus, Catulus. in his etiam agnoscimus gentium uitia; labdacismis scatent Afri, raro est ut aliquis dicat $l$ : per geminum $l$ sic locuntur Romani, omnes Latini sic locuntur, $\mathrm{Ca}$ tullus, Metellus. ${ }^{9}$

\footnotetext{
${ }^{3}$ Apul. Flor. 9: ... et vestra de me benigna praesumptio nihil non quicquam sinit neglegenter ac de summo pectore hiscere. Quis enim vestrum mihi unum soloecismum ignoverit? quis vel unam syllabam barbare pronuntiatam donaverit? quis incondita et vitiosa verba temere quasi delirantibus oborientia permiserit blaterare? Détshy Mihály fordításában: „...jóindulatú hajlandóságotok sem engedi, hogy akár egyetlen szót is pongyolán vagy megfontolatlanul ejtsek. Ki nézné el nekem köztetek egyetlen nyelvbotlásomat is? Ki bocsátaná meg nekem, ha csak egyetlen szótagot is barbár kiejtéssel mondanék? Ki tűrné, ha holmi pórias vagy kevéssé választékos szavakat fecsegnék itt össze ötletszerűen, ahogy eszelősök agyában merülnek föl?”

${ }^{4}$ Adamik B.: A császárkori feliratok vulgáris latin nyelvi adatainak dialektológiai érvényessége. AntTan 56 (2012) 91-105.

${ }^{5}$ Adamik: i. m. (4. jegyz.) 92.

${ }^{6}$ Herman: i. m. (1. jegyz.) 24.

${ }^{7}$ Herman: i. m. (1. jegyz.) 23.

${ }^{8}$ Pompeius (Kr. u. V. sz. vége - VI. sz. eleje) afrikai származású grammatikus.

${ }^{9}$ H. Keil: Grammatici Latini Vol. V. Artium scriptores minores. Lipsiae 1868. 286, 34-287, 6.
} 
A labdacismus az, amely vagy egy $l$ vagy pedig kettő révén valósul meg; tehát egy $l$ révén, ha „vékonyabban”, kettő által, ha „kövérebben” hangzik. Gondolj a llargus-ra, melyet úgy kell mondanunk, hogy largus, úgy, hogy kövéren hangozzék, és ugyanígy, ha azt mondod, llex és nem azt, hogy lex. Ezek hibásak a labdacismus miatt. Hasonlóképp a kettős $l$ esetén, ha „kövérebben” szeretnéd hangoztatni, ha azt mondanánk, hogy Metelus, Catulus. Ezekben az esetekben pedig a különböző népek tévesztési sajátosságait ismerhetjük fel. Az afrikaiak hemzsegnek a labdacismusoktól, ritka, hogy valaki egy $l$-t mondjon. Kettő $l$ révén mondják a rómaiak, minden latin úgy mondja, hogy Catullus, Metellus. ${ }^{10}$

Pompeius kifejezetten az afrikai latin beszélőkhöz társítja ezt a jelenséget, és összemossa az $l$ hang kétféle ejtésmódját a gemináció, tehát a megkettőződés kérdésével. ${ }^{11} \mathrm{~A}$ labdacismus tehát az $l$ hang kétféle - tenuius és pinguius - ejtésével kapcsolatos tévesztés, mely bizonyos mértékben összefügg az $l$ gemináta helytelen használatával. Eredetileg azonban háromféle hangzást különbözetett meg a grammatikusi hagyomány az $l$ hang tekintetében, ezt az alábbi, Priscianusnál található szövegrészletben olvashatjuk: ${ }^{12}$

$l$ triplicem, ut Plinio videtur, sonum habet: exilem quando geminatur secundo loco posita, ut ille, Metellus; plenum quando finit nomina uel syllabas et quando aliquam habet ante se in eadem syllaba consonantem, ut sol, silua, flauus, clarus; medium in aliis, ut lectum, lectus. ${ }^{13}$

Az $l$ hangnak, ahogy Pliniusnál látjuk, háromféle hangzása van: vékony, amikor megkettőződik és a gemináta második tagja, miként az ille, Metellus; telt, amikor a szó vagy a szótag végén áll és amikor előtte ugyanabban a szótagban valamilyen mássalhangzó áll, például sol, silua, flauus, clarus; köztes egyéb esetekben, mint lectum, lectus.

A harmadik kategória, a sonus medius a lágyabb (exilis, tenuis) és a kövérebb, teltebb (pinguis, plenus) ejtés között helyezkedik el. Valamiféle köztes hangzás lehetett minden olyan esetben, amikor nem kellett kifejezetten lágy vagy telt $l$-t használni, így például a szókezdő $l$ hang ejtésekor (lectum, lectus). Ha visszatérünk a pompeiusi idézethez, láthatjuk, hogy ez a „középső hangzás” eltűnik, jobban mondva beolvad a helyesen használt pinguis ejtésbe. Pompeius első példája - largus - jól szemlélteti ezt, hiszen $l$ hanggal kezdődik, mely korábban a medius sonusra volt példa. Ennek oka az lehet, hogy valószínúleg már maguk a grammatikusok sem érezhették, hallhatták teljesen jól a háromféle ejtés közötti különbséget.

${ }^{10}$ A szövegben előforduló grammatikusi idézetek magyar változatát saját fordításomban közlöm.

${ }^{11}$ Adams: i. m. (2. jegyz.) 267.

12 Priscianus Caesariensis (Kr. u. V-VI. sz.) a mauretaniai Caesareából származó grammatikus.

${ }^{13}$ H. Keil - M. Hertz: Grammatici Latini Vol. II. Prisciani Institutionum Grammaticarum Libri I-XII. Lipsiae 1855. 29, 8-12. 
Sidney Allen Vox Latina címü munkájában az $l$ mássalhangzó tárgyalásakor idézi ezt a Pliniushoz köthető részletet az $l$ hang kétféle ejtése kapcsán, mely szerinte az angol nyelvben használatos kétféle, ún. clear és dark $l$ hangzásához hasonlatos. ${ }^{14}$ Előbbi (clear) magánhangzók előtt (look, silly), utóbbi (dark) pedig minden más esetben, tehát például mássalhangzó előtt vagy szóvégen valósul meg (így hill, field). Az angol dark $l$ ejtésekor egy veláris (hátul képzett) $l$ hangra, míg a clear $l$ esetében egy palatális (tehát elöl képzett) $l$ hangra kell gondolnunk. Hasonló dolog történik szerinte a latinban is. ${ }^{15}$ Plinius a plenus terminussal nevezi meg az $l$ hang azon ejtésmódját, mikor az a szótag vagy szó végén áll, illetve mássalhangzó előtt valósul meg. Ezek a helyzetek nagyon hasonlítanak az angol dark $l$ használatához, így feltételezhetjük, hogy a latin esetében is egy ilyen veláris $l$ hang valósulhatott meg a helyes plenus ejtéskor, melyet a későbbi grammatikusok a pinguis kifejezéssel illettek. ${ }^{16}$ Ezzel szemben áll az exilis hangzás, mely az $l$ hang lágyabb, finomabb minőségét fejezi ki, mely Pliniusnál csak a gemináta $l$ második tagjára vonatkozik (exilem quando geminatur secundo loco posita, ut ille, Metellus). Azonban a későbbi grammatikusok számára már nem egyértelmü, hogy mikor kell az exilis ejtést használni, mindannyian máshogy próbálják meghatározni ennek helyzetét, előfordulását. Ami azonban közös, hogy mindannyian - talán a pliniusi helyből kiindulva - az $l$ geminátához kapcsolják az exilis hangzást. Ezt láthatjuk Pompeiusnál is: per duo, si pinguius sonet, majd kicsit később: item in gemino l, még a példa is hasonló a pliniusi helyhez: Metellus, Catullus Pompeiusnál, ille, Metellus Pliniusnál. Tehát idővel még zavarosabbá vált a labdacismus fogalma, hiszen a grammatikusok a lágy hangzás esetét kiterjesztik a geminációra - tehát az - $l l$ - egészére -, és nem veszik figyelembe, hogy eredetileg az csak a gemináta második tagjában valósult meg.

Consentius ${ }^{17}$ szerint a labdacismus hibája abban áll, hogy vagy finomabban (subtilius), vagy pedig kövérebben, súlyosabban (pinguius) ejtődik a hang: ${ }^{18}$

${ }^{14}$ W. Sidney Allen: Vox Latina. A Guide to the Pronunciation of Classical Latin. Cambridge 1978. $33-34$.

${ }^{15}$ Allen: i. m. (14. jegyz.) 33.

${ }^{16}$ A latin grammatikusok a hátul képzett magánhangzók esetében a plenus és a pinguis kifejezést használják, míg az elöl képzett magánhangzóknál az exilis terminust. Vö. Allen: i. m. (14. jegyz.) 34.

${ }^{17}$ Publius Consentius (Kr. u. V. sz. körül) valószínűleg Gallia Narbonensisből származó latin grammatikus.

${ }^{18}$ Consentius az idézett rész előtt más hibákról is ír, így például közvetlenül a labdacismus előtt a iotacismusról, az $i$ hanggal kapcsolatos tévesztésről, ahol szintén háromféle - pinguis, exilis, medius sonus - ejtésről beszél: iotacismum dicunt vitium quod per i litteram vel pinguius vel exilius prolatam fit. Galli pinguius hanc utuntur, ut cum dicunt ite, non expresse ipsam proferentes, sed inter e et i pinguiorem sonum nescio quem ponentes. Graeci exilius hanc proferunt, adeo expressioni eius tenui studentes, ut, si dicant ius, aliquantulum de priori littera sic proferant, ut videas dissyllabum esse factum. Romanae linguae in hoc erit moderatio, ut exilis eius sonus sit, ubi ab ea verbum incipit, ut ite, aut pingior, ubi in ea desinit verbum, ut habui tenui; medium quendam sonum inter e et $i$ habet, ubi in medio sermone est, ut hominem. mihi tamen videtur, quando producta est, plenior vel acutior esse; quando autem brevis est, medium sonum exhibere debet, sicut eadem exempla, quae posita sunt, possunt declarare. (Keil: i. m. [9. jegyz.] 394, 11-21.) 
Labdacismum uitium in eo esse dicunt, quod eadem littera uel subtilius a quibusdam uel pinguius ecfertur. ${ }^{19}$

Azt mondják, hogy a labdacismus hibája abban áll, hogy ugyanazt a betüt egyesek vékonyabban vagy kövérebben ejtik (mint kellene).

Majd néhány sorral lejjebb így folytatja:

Romana lingua emendationem habet in hoc quoque distinctione. nam alicubi pinguius, alicubi debet exilius proferri; pinguis cum uel $b$ sequitur, ut in albo, uel $c$, ut in pulchro, uel $f$, ut in adelfis, uel $g$, ut in alga, uel $m$, ut in pulmone, uel $p$, ut in scalpro; exilius autem proferenda est, ubicumque ab ea uerbum incipit, ut in lepore, lana, lupo, uel ubi in eodem uerbo et prior syllaba in hac finitur et sequens ab ea incipit, ut ille et Allia. ${ }^{20}$

A római nyelv e különbségtétel tekintetében is helyes megoldást nyújt. Ugyanis valahol kövérebben, valahol pedig vékonyabban (lágyabban) kell ejteni. Kövérebben, amikor vagy $b$ követi, mint az albusban, vagy $c$, mint a pulcherben, vagy $f$, mint az adelfiben, vagy $g$, mint az algaban, vagy $m$, mint a pulmoban, vagy $p$, mint a scalprumban. Vékonyabban (lágyabban) kell ejteni, valahányszor a szó elején áll, mint lepus, lana, lupus, vagy, amikor ugyanabban a szóban az előző szótag vele végződik és a következő (szótag) is vele kezdődik, mint ille és Allia.

Consentius is csak két kategóriát említ, az $l$ hangnak a lágyabb, illetve a teltebb, kövérebb ejtését, utóbbiba azonban beleolvasztja a harmadik, medius sonus esetet, miközben Pompeiusnál azt láthattuk, hogy a szókezdő $l$ kiejtése (largus) még a pinguis, telt hangzáshoz sorolódik.

Míg Pompeiusnál az $l$ hangnak a szón belül elfoglalt helye kevéssé számít - szemben a pliniusi hellyel, ahol ez határozza meg az $l$ három eltérő minőségét -, Consentius megpróbálja meghatározni, hogy mely ejtésnél hol található a szón belül az $l$ hang, nem túl sok sikerrel. A szókezdő pozíció eleve a medius ejtést jelentette, amikor pedig a gemináta-helyzetről ír, szintén kihagyja a lényeget, miszerint a lágyabb ejtés csak a gemináta második tagjára vonatkozik. A teltebb, kövérebb ejtésmódot pedig ahhoz köti, hogy milyen mássalhangzók előzik meg az $l$ hangot, hat példát sorolva fel minden esethez $(b, c, f, g, m, p)$, míg Pliniusnál csupán annak a feltételnek kellett érvényesülnie, hogy ugyanabban a szótagban valamilyen mássalhangzó előzze meg az $l$ hangot (plenum [...] quando aliquam habet ante se in eadem syllaba consonantem).

${ }^{19}$ Keil: i. m. (9. jegyz.) 394, 22-24.

${ }^{20}$ Keil: i. m. (9. jegyz.) 394, 29-36. 
Servius, mikor a különféle nyelvi hibákat sorolja fel, a következő rövid megjegyzést teszi a labdacismusról: ${ }^{21}$

Labdacismi fiunt, si aut unum $l$ tenuius dicis, [solocismus] ut Lucius, aut geminum pinguius, ut Metellus. ${ }^{22}$

A labdacismusok akkor történnek, ha vagy egy l-t vékonyabban mondasz, mint Lucius, vagy kettőt kövérebben, mint Metellus.

Servius lényegre törő, rövid megfogalmazása szerint egy $l$-t teltebben, kettőt pedig - tehát a geminátát - gyengébben, vékonyabban kell ejteni. Ezek alapján úgy tünik, hogy a labdacismus lényege abban állt, hogy a két, lágyabb és teltebb ejtést rosszul használták, azaz felcserélték őket, és a helyes ejtést ahhoz kötötték, hogy egy $l$ vagy pedig gemináta szerepel-e az adott szóban.

Ezt a „zavart” fedezhetjük fel Sevillai Szent Izidornál is a VI-VII. században, ${ }^{23}$ aki a következőképp határozza meg a labdacismust: ${ }^{24}$

labdacismus est, si pro una $l$ duo pronuntientur, ut Afri faciunt, sicut colloquium pro conloquuium; vel quotiens unam $l$ exilius, duo largius proferimus. quod contra est; nam unum largius, duo exilius proferre debemus. ${ }^{25}$

A labdacismus az, hogy ha egy $l$ helyett kettőt ejtenek, ahogy az afrikaiak teszik, miként colloquium conloquium helyett; vagy valahányszor egy $l$-t vékonyabban, kettőt pedig kövérebben ejtünk, ami az ellenkezője annak, ahogy ejtenünk kellene, ugyanis egyet kövérebben, kettőt vékonyabban kell mondanunk.

Egyértelmű, hogy Izidornál már a labdacismus részévé válik az $l$ helytelen geminációja, labdacismus est, si pro una l duo pronuntientur, azaz „a labdacismus az, hogy ha egy 1 helyett kettőt ejtenek". Azonban erre vonatkozó példájának - tehát a colloquium a conloquium helyett - nincs köze az $l$ hang ejtéséhez, hiszen a prefixum hasonulásáról van szó jelen esetben. ${ }^{26}$ Mindkét változat klasszikus, az egyik etimologikus írásmódú (con-l-), a másik hasonult (col-l). A szövegrészlet második feléből (nam unum largius, duo exilius proferre debemus) is nyilvánvaló, hogy az $l$ hang két eltérő hangzásának megfelelő, helyes használata összemosódott az $l$ gemináta/degemináta helyzetével.

Izidor rövid megjegyzése azonban, miszerint ez a fajta tévesztés az afrikaiakra különösen jellemző (ut Afri faciunt), azonosságot mutat Pompeius szövegével, aki szintén

${ }^{21}$ Marius (vagy Maurus) Servius Honoratus (Kr. u. IV. sz.) grammatikus, kommentátor.

${ }^{22}$ H. Keil: Grammatici Latini Vol. IV. Probi, Donati, Servii qui feruntur de arte grammatica libri, et notarum laterculi. Lipsiae 1864. 445, 12-13.

${ }^{23}$ Sevillai Szent Izidor (Isidorus Hispalensis, Kr. u. 556-636) Sevilla püspöke.

${ }^{24}$ Adams: i. m. (2. jegyz.) 267.

${ }^{25}$ Isid. Etym. 1, 32, 8.

${ }^{26}$ Adams: i. m. (2. jegyz.) 268. 
fontosnak tartotta kiemelni, hogy az afrikaiak hemzsegnek a labdacismusoktól (labdacismis scatent Afri).

Láthatjuk tehát, hogy már az idézett, késő ókori grammatikusoknál is zavaros a labdacismus meghatározása és értelmezése, mely valahol korábban, a grammatikusi hagyományban alakulhatott ki és hagyományozódhatott tovább ebben a formában. ${ }^{27}$ Amellett, hogy az $l$ hang eltérő ejtései idővel összemosódtak, és elkezdték azt összekötni az $l$ téves geminációjával és degeminációjával, egyfajta népnyelvi sajátosságot véltek felfedezni a labdacismus jelenségében, melyet az afrikai beszélőkhöz társítottak.

Ha az $l$ hang ejtését nem is, helyes vagy helytelen geminációját és degeminációját meg tudjuk vizsgálni az afrikai feliratos anyagon. A szemléltetés kedvéért az eredményeket a Római Birodalom központjával, Rómával hasonlítom össze, hiszen a fóvárosban rengeteg felirat található, az észak-afrikai terület pedig ehhez hasonlóan bővelkedik feliratokban és adatokban. Az Adatbázison belül Róma után az észak-afrikai provinciákból származik a legtöbb adat, annak ellenére, hogy feldolgozásuk még közel sem ért véget. Az itt felhasznált adatok Africa proconsularis és Numidia területéről származnak. ${ }^{28}$

Az 1 > LL téves geminációját - tehát amikor egy $l$ helyett duplát használnak tévesen, például a klasszikus nomen gentile Aurelius vagy nőnemben Aurelia helyett AVRELLIVS vagy AVRELLIAE jelenik meg, ${ }^{29}$ - az $I / a$ és $I / b$ ábra diagramjai szemléltetik, először a korai, majd a kései Afrikában, és ugyanígy Rómában.

Az $l$ geminációja egyértelműen Rómában a jelentősebb. A korai korszak tekintetében még csak 2\%-kal előzi meg Észak-Afrikát: Rómában 23\%, míg Afrikában 21\% az $l$ téves geminációja. Azonban ez az arány a IV-VII. századra erősen megváltozik: míg Afrikában a kései korszakra 21\%-ról 13\%-ra csökken, addig Rómában növekedési tendenciát láthatunk, itt 23-ról 31\%-ra nő a százalékszám, a geminációk közel harmada l-tévesztésekhez sorolható. Sőt, a kései Rómában látható 31\% kicsivel több mint a duplája a kései Afrikában mutatkozó 13\%-nak. Érdekes, hogy míg Afrikában 8\%-kal csökken, addig Rómában pont 8\%-kal nő az arány.

A degeminációk, tehát az egyszerüsödés esetében, amikor dupla $l$ helyett egyet használnak tévesen, például a klasszikus Gemellina helyett GE|MELINA vagy a szintén

${ }^{27}$ Adams: i. m. (2. jegyz.) 268.

${ }^{28}$ A felhasznált adatok a 2019. március 1-i állapotot tükrözik. Fontos itt megjegyezni, hogy a feliratgyüjtemények nem egységesek a két provinciát illetően, hiszen Numidia csupán Septimius Severus uralkodása alatt lesz önálló tartomány, így egyes korpuszok, melyek a korábbi területi felosztást veszik figyelembe, a numidiai feliratokat Africa proconsularishoz sorolják be. Azonban az Adatbázis keretein belül mindig a Septimius Severus által kijelölt határokkal dolgozunk, külön kezelve a két tartományt, így jelen tanulmányban is Észak-Afrika Numidia és Africa proconsularist fogja jelenteni. Következésképpen a legnyugatibb észak-afrikai tartomány, Mauretania feliratos anyagának bevonása a következő lépés lesz e komplex probléma feldolgozásában.

${ }^{29}$ LLDB-42709: 1 > LL, AV|RELLIAE = Aureliae, ILAlg 1, 241, 1-2 = CIL 8, 5328, 1-2, Africa proconsularis, Calama, Kr. u. 170-217. LLDB-82636: $1>$ LL, AVRELLIVS = Aurelius, LBIRNA 454, $9=$ AE 1963, 144d, 9, Africa proconsularis, Leptis Magna, Kr. u. 215-216. 
klasszikus Tullio helyett a TVLIO használata, ${ }^{30}$ a $I I / a$ és $I I / b$ ábra diagramjai mutatják a megoszlási arányokat, szintén először a korai, majd a kései korszakban.

A korábbiakhoz hasonlóan itt is azt látjuk, hogy Rómában jelentősebb az $l$ téves degeminációja, a korai Afrikában ez 16\%, míg Rómában ugyanígy az I-III. században már $22 \%$. A kései korszakra azonban a degemináció tekintetében mindkét területen hasonló csökkenést láthatunk - szemben az l-geminációval, ahol Afrikában csökkenést, Rómában pedig növekvést mutattak a diagramok. Az észak-afrikai provinciákban 16\%-ról a felére, 8\%-ra csökken az $l$ degeminációjának előfordulása, ahogy Rómában is 22\%-ról szintén a felére, $11 \%$-ra esik vissza az $l$-degeminációk százalékszáma. Afrikában itt is a geminációhoz hasonlóan - szintén 8\%-kal csökken, Rómában pedig 11\%-kal.

A rendelkezésünkre álló, eddig feldolgozott afrikai és római feliratos anyag elemzéseiből arra következtethetünk, hogy a tárgyalt grammatikusi helyek forrása eredetileg inkább csak az $l$ variáns kiejtése körüli anomáliákra vonatkozhatott. Ennek a tekintetében lehetett valamiféle afrikai sajátosság, amit valamelyik grammatikus észrevehetett, de mikorra ez az észrevétel a későbbi grammatikusokhoz, akik a jelenséggel foglalkoztak, eljutott, már valószínűleg nem volt jelentősége, azaz nem volt érzékelhető az $l$ eltérő ejtése. Így - mivel nem igazán értették már, hogy miben áll a jelenség lényege - elkezdték egybemosni a gemináták/degemináták, azaz az $l$ normatív szempontból téves nyújtásának és rövidítésének problémájával, ahogy ez például Sevillai Izidor szövegéből is nyilvánvaló.

Így tehát - ennek figyelembevételével - megállapíthatjuk, hogy a tanulmány címében feltett kérdésre a válasz kettős: egyrészt az $l$ hang ejtésében valóban lehetett valamiféle „afrikai” sajátosság, de ez már a késő ókorban elveszthette jelentőségét. Másrészt azonban az $l$ geminációja és degeminációja nem tekinthető kifejezetten az afrikai latinságra jellemző barbarismusnak, a feliratokon mind a korai, mind a kései korban nagyobb arányban mutatkoznak Rómában ezek a tévesztések. Úgy tűnik tehát, ebben az esetben a Római Birodalom központjában semmivel sem beszéltek helyesebben vagy „klasszikusabban”, legalábbis, ami a nép emberét illeti, mint a meghódított és a magukat műveltségi fölényben érző grammatikusok által sokszor lenézett provinciák lakói.

\author{
Bohacsek Dóra \\ ELTE BTK Nyelvtudományi Doktori Iskola \\ Ókortudományi Program \\ 1088 Budapest, Múzeum krt. 4/F \\ bohacsekdora@gmail.com
}

A cikk a Creative Commons Attribution 4.0 International License (https://creativecommons.org/ licenses/by/4.0) feltételei szerint publikált Open Access közlemény, melynek szellemében a cikk bármilyen médiumban szabadon felhasználható, megosztható és újraközölhető, feltéve, hogy az eredeti szerző és a közlés helye, illetve a CC License linkje és az esetlegesen végrehajtott módosítások feltüntetésre kerülnek. (SID_1)

${ }^{30}$ LLDB-86250: 11 > L, TVLIO = Tullio, LBIRNA 732, 11 = AE 1911, 110, 11, Numidia, Cuicul, Kr. u. 364-367. LLDB-71606: 11 > L, GE|MELINA = Gemellina, ILAlg 1, 3369, 2-3 = CIL 8, 27896, 2-3, Africa proconsularis, Theveste, Kr. u. 51-300. 
Gemináció Észak-Afrikában a korai korszakban (Kr. u. I-III. sz.)

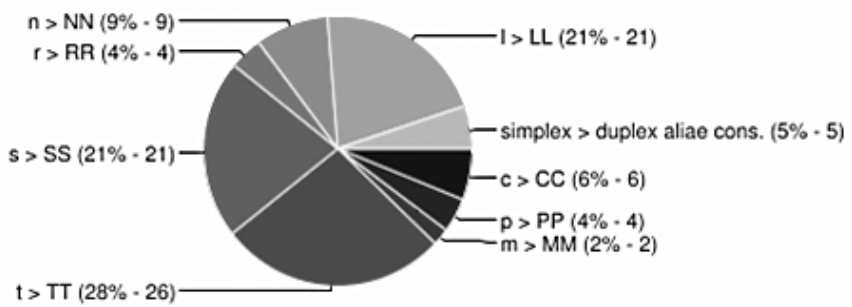

Gemináció Rómában a korai korszakban (Kr. u. I-III. sz.)

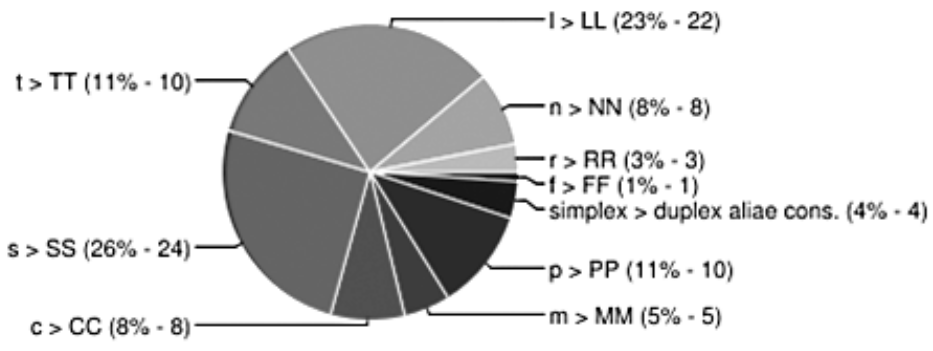

1/a. ábra.

Gemináció Észak-Afrikában a kései korszakban (Kr. u. IV-VII. sz.)

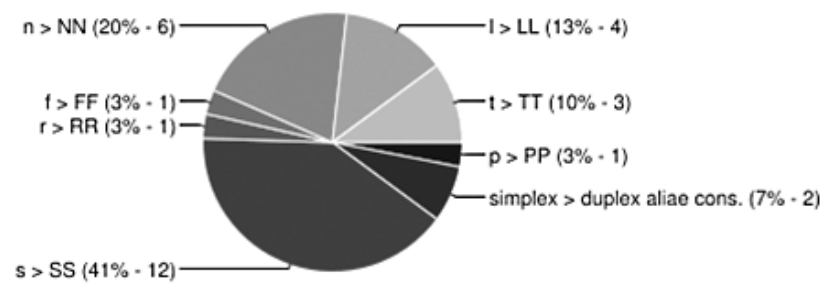

Gemináció Rómában a kései korszakban (Kr. u. IV-VII. sz.)

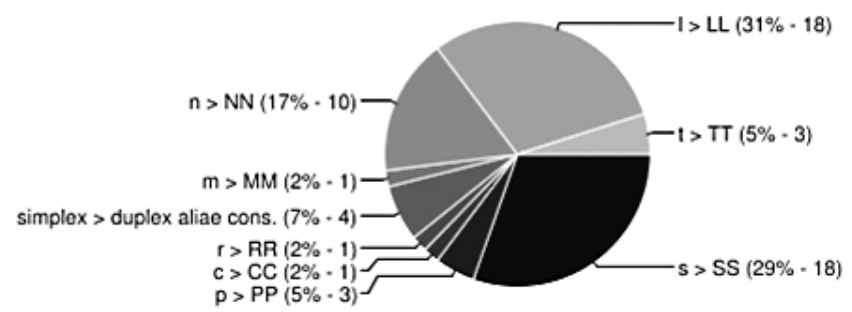

1/b. ábra. 
Degemináció Észak-Afrikában a korai korszakban (Kr. u. I-III. sz.)

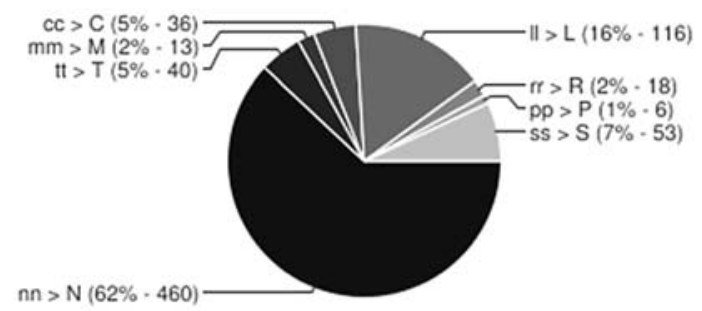

Degemináció Rómában a korai korszakban (Kr. u. I-III. sz.)

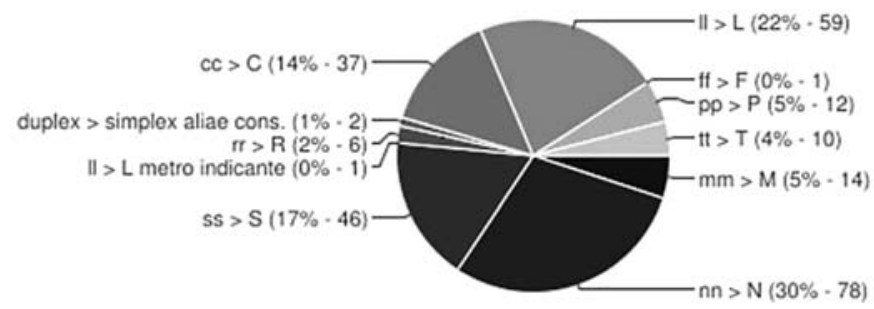

2/a. ábra.

Degemináció Észak-Afrikában a kései korszakban (Kr. u. IV-VII. sz.)

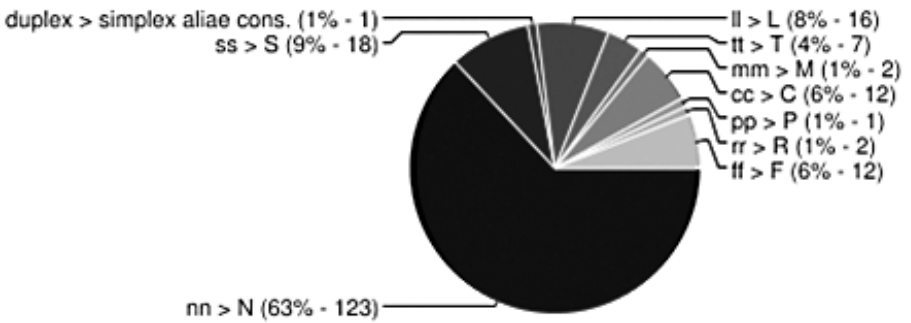

Degemináció Rómában a kései korszakban (Kr. u. IV-VII. sz.)

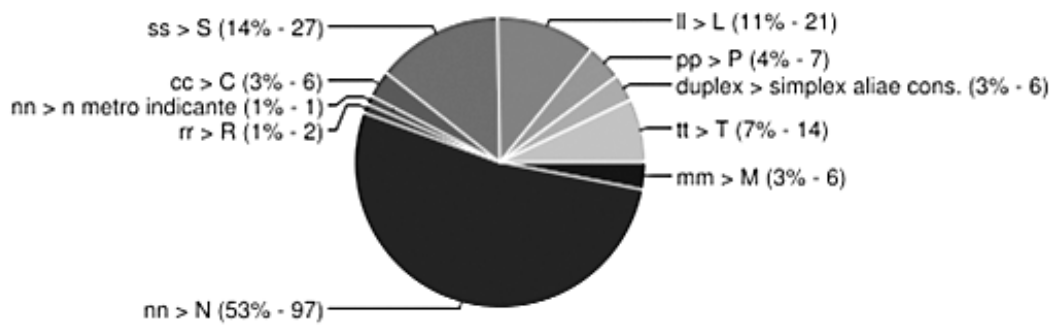

2/b. ábra. 